Reprod. Nutr. Dévelop., 1982, 22 (4), 621-630.

\title{
Effects of induced hypoprolactinaemia in the ram : plasma gonadotrophin levels, LH and FSH receptors and histology of the testis.
}

\author{
B. BARENTON (1), M. T. HOCHEREAU-de REVIERS (2), C. PERREAU, \\ J.-C. POIRIER
}

Station de Physiologie de la Reproduction, I.N.R.A. Nouzilly, 37380 Monnaie, France.

\begin{abstract}
Summary. In order to investigate the effects of induced hypoprolactinaemia on gonadotrophin levels and testicular function in the ram, CB 154 was administered either in summer under natural photoperiod or in winter combined with a light regime stimulating prolactin release.

Under natural photoperiod in summer, plasma FSH levels increased from 2.5 to $4 \mathrm{ng} / \mathrm{ml}$ in controls and from 2.5 to $8 \mathrm{ng} / \mathrm{ml}$ in CB 154-treated rams. Control and treated groups differed significantly $(P<0.05)$ from the second week of treatment onwards. In the animals photostimulated in winter, treatment with $\mathrm{CB} 154$ did not change plasma FSH levels ; no effect of CB 154 on plasma $\mathrm{LH}$ levels was detected in either experiment.

Treatment with CB 154 in summer led to an increase in the volumes of peritubular blood vessels and interstitial tissue. The number of Leydig cells per testis was significantly $(P<0.05)$ increased in CB 154-treated rams. However, at the time of measurement, there was no change in the structure of the seminiferous tubules or in the production of germ cells. In winter in photostimulated animals, no effect of treatment with CB 154 was detected either on the structure of interstitial and tubular compartments or on spermatogenesis.

The change in prolactin levels affected neither the number of $\mathrm{LH}$ receptors, expressed per Leydig cell, nor the number of FSH receptors, expressed per Sertoli cell, in the experiments. It is concluded that induced hypoprolactinaemia can modify the release of FSH in the ram and change the structure of the intertubular tissue but that it does not affect the number of $\mathrm{LH}$ and $\mathrm{FSH}$ receptors or impair spermatogenesis.
\end{abstract}

\section{Introduction.}

The exact role of prolactin in testicular function is still uncertain, but is appears that this hormone in the rat is directly involved in maintaining luteinizing hormone (LH) receptors (Zipf et al., 1978) and the responsiveness of the Leydig cells to LH (Purvis et al., 1979). In hamsters, which have regressed testes when Cedex.

(') Present address : I.N.R.A. E.N.S.A., Station de Physiologie animale, 34060 Montpellier

$\left.{ }^{2}\right)$ Person to whom reprint requests should be addressed. 
exposed to short daylengths, a single injection of prolactin increases the number of LH receptors and testicular weight (Bex et al., 1978). Recent investigations have also shown that induced hyperprolactinaemia increases the release of follicle-stimulating hormone (FSH) in the hamster (Bartke et al., 1981) and that of both LH and FSH in the mouse (Klemcke and Bartke, 1981).

In the ram, we have reported that the inhibition of prolactin release by bromocryptine (CB 154) injections leads only to a delay in testicular growth, rapidly followed by a recrudescence of the testis (Barenton and Pelletier, 1980). This unexpected response suggested that prolactin could act directly on the structure of the testis or by modifying the release of gonadotrophic hormones at the pituitary level. Therefore, further investigations were carried out on these same animals to test these hypotheses. In the present study, we measured plasma levels of FSH and LH, performed a quantitative examination of the histology of the testes and estimated the number of $\mathrm{LH}$ receptors per Leydig cell and of FSH receptors per Sertoli cell.

\section{Material and methods.}

Protocol. - The first experiment (exp. 1), lasting 50 days, was carried out at the onset of the breeding season under natural photoperiod in summer. We induced hypoprolactinaemia in 3 of the 6 Romanov rams by giving two daily s.c. injections of $2 \mathrm{mg} \mathrm{CB} 154$ (Sandoz Ltd., France) each. The other 3 animals acting as controls were given the solvent only.

The second experiment (exp. II), lasting 43 days, was carried out during the non-breeding season in winter. In order to stimulate the release of prolactin, 10 Préalpes du Sud rams were subjected to a daily artificial photoperiod of $7 \mathrm{~h}$ of light with an additional light pulse given 16-17 $\mathrm{h}$ after dawn (Ravault and Ortavant, 1977). Five animals received CB 154 as outlined above. The other 5 animals acted as controls.

The testes were surgically removed at the end of each experiment after local anaesthesia, obtained by injection of $5 \mathrm{ml}$ Sylvocaine (Mérieux, F) in the two spermatic cords. The testicular material used for histological investigations and assays of gonadotrophin receptors was taken from the left testis.

Hormone assays. - Weekly blood samples were taken by jugular venipuncture between 0900 and $0930 \mathrm{~h}$. After centrifugation, the plasma samples were stored at $-15^{\circ} \mathrm{C}$ until assayed. Plasma prolactin (Kann, 1971), FSH (Blanc and Poirier, 1979) and LH (Pelletier et al., 1968) were measured by double antibody radioimmunoassay using NIH-P-S6, HG-FSH-225 (= $2.6 \mathrm{NIH-FSH}-\mathrm{S} 3$ )

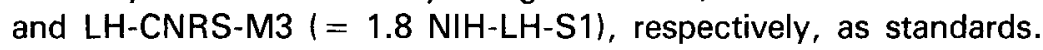

Histology. - Fragments of testicular tissue were fixed in Bouin's solution and embedded in paraffin wax, and 10- $\mu \mathrm{m}$ sections were cut for histological studies. The cycle of the seminiferous epithelium was classified into the eight stages described by Roosen-Runge and Giesel (1950) for the rat. The type $A_{1}$ spermatogonia and the Sertoli cells were counted in ten cross-sections of seminiferous tubules at stages 7.8 and 1 , and round spermatids were counted in the same sections but at stage 8 only. The total counts were corrected for differences in nuclear volume by the formula of Abercrombie (1946), modified by 
Ortavant (1959), but no correction was made for the Sertoli cells since they have an irregular shape. The tubular diameter was measured on 20 cross-sections per testis. The relative volume of the intertubular tissue, as compared to the seminiferous tubules, was determined with a 25-point ocular integrator (Hennig, 1957) on 20 microscopic fields per testis. The relative proportion of Leydig cells and blood vessels was compared to that of the other intertubular cells using the same method.

The profile surface area of Leydig cell cytoplasm and Sertoli cell nuclei was measured on 20 randomly selected cells per animal with a microscopic-area measuring system (AMS, Leitz), and the mean volume of the Leydig cells was determined. The total length of the seminiferous tubules per testis was calculated from the above data by the formula of Attal and Courot (1963). The total number of type $A_{1}$ spermatogonia per testis was calculated from the total length of the seminiferous tubule and the mean corrected number of cells per $10 \mu \mathrm{m}$ tubular cross-section. The daily productions of $A_{1}$ spermatogonia and of round spermatids per testis were calculated from the total number per testis and the duration of the seminiferous epithelium cycle which is 10.4 days (Ortavant, 1959).

Estimation of the numbers of $\mathrm{LH}$ and FSH receptors per target cell. - the binding of ovine $\mathrm{LH}$ (oLH-CNRS-M3) and ovine FSH (oFSH-CNRS-P26 $=14$ $\mathrm{NIH}-\mathrm{FSH}-\mathrm{S} 3$ ) to testicular membrane preparations was assessed using hormones radioiodinated with 125 ( Centre, Amersham, Bucks.) by the lactoperoxidase-plus-glucose-oxidase method (Tower et al., 1977). The specific activities of ${ }^{125}$ /-labelled ovine $\mathrm{LH}$ and ${ }^{125}$ labelled ovine $\mathrm{FSH}$ were $20-40 \mathrm{Ci} / \mathrm{g}$ and $30-50 \mathrm{Ci} / \mathrm{g}$, respectively.

The numbers of $\mathrm{LH}$ receptors were measured as described previously by Barenton and Pelletier (1980). The numbers of FSH receptors were measured according to the method of Cheng (1975) as described for bovine FSH receptors, but using the same preparation of ovine testicular membranes as for $\mathrm{LH}$ receptors and an homologous hormonal system. The results were first expressed as femtomoles of hormones bound per milligram of membrane protein and calculated per testis. These were then multiplied by Avogadro's number $\left(6.02 \times 10^{23}\right)$ and divided by the relevant number of target cells in the testis to obtain the mean number of binding sites per cell. LH receptors were assumed to be located in Leydig cells and FSH receptors in Sertoli cells (Mancini et al., 1967).

Statistical analysis. - Comparison between treated and control groups were made using Student's t-test.

\section{Results.}

Effects of the treatment of prolactin levels. - In the first experiment, plasma prolactin levels remained around $200 \mathrm{ng} / \mathrm{ml}$ in the controls but fell from 200 to less than $5 \mathrm{ng} / \mathrm{ml}$ in CB 154-treated rams (fig. 1a). Under the effect of the light regime, plasma prolactin levels increased from 30 to more than $100 \mathrm{ng} / \mathrm{ml}$ in the controls of the second experiment but fell from 30 to less than $5 \mathrm{ng} / \mathrm{ml}$ in СВ 154-treated animals (fig. 1b). 

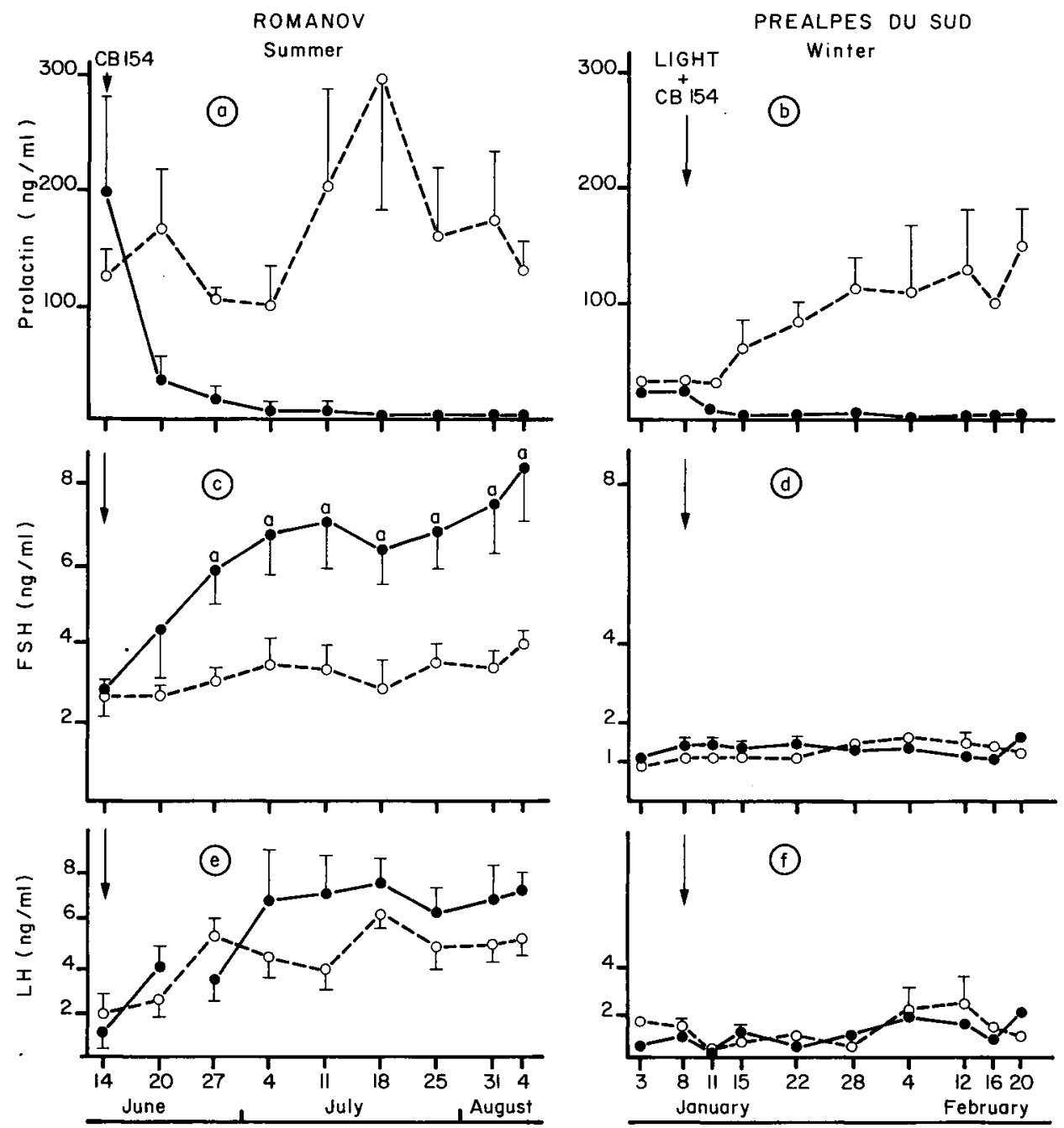

FIG. 1. - Effect of treatment with bromocryptine on the release of prolactin (a, b), FSH (c, d) and $L H(\mathrm{e}, \mathrm{f})$ in rams under natural photoperiod in summer (Exp. I) (a, $c$ and e) or in rams subjected to a constant light regime stimulating the release of prolactin in winter (Exp. II) (b, $\mathrm{d}$ and $\mathrm{f}$ ). -.-O : Controls ; - $\bullet$ : CB 154-treated rams ; Means \pm SEM ; (a) significantly different from controls $(\mathrm{P}<0.05)$.

Effects on LH and FSH levels. - Figure 1 shows the levels of FSH and LH in the plasma during experiments $I$ and II. Under natural photoperiod in summer (exp. I), plasma levels of $\mathrm{FSH}$ increased from 2.5 to $8 \mathrm{ng} / \mathrm{ml}$ in CB-154-treated Romanov rams and from 2.5 to $4 \mathrm{ng} / \mathrm{ml}$ in the control group (fig. 1c). The difference between the treated and the control groups was significant $(P<0.05)$ from the second week of treatment onwards. The mean plasma level of $\mathrm{LH}$ increased from 2 to $5 \mathrm{ng} / \mathrm{ml}$ in the controls and from 1.5 to $7 \mathrm{ng} / \mathrm{ml}$ in CB 154treated rams, but the two groups did not differ significantly (fig. 1e). 
In rams photostimulated in winter (exp. II), plasma levels of FSH varied around $1 \mathrm{ng} / \mathrm{ml}$ (fig. 1d) and plasma levels of $\mathrm{LH}$ varied around $1.5 \mathrm{ng} / \mathrm{ml}$ (fig. 1f). No significant difference for either hormone was found between the control and the CB 154-treated groups.

Effects on testicular weight and intertubular spaces (fig. 2). - The testicular weight, measured at the end of each experiment, was always similar in the control and the treated groups (fig. 2a). In the rams injected with CB 154 in summer (exp. I), there was a highly significant $(P<0.001)$ increase in the total intertubular volume per testis (fig. $2 \mathrm{~b}$ ). This was the result of a significant $(P<0.05)$ increase of the volume of both the blood vessels (fig. $2 c$ ) and the interstitial tissue (fig. 2d). In rams photostimulated in winter (exp. II), these volumes tended to be lower in CB 154-treated animals (figs. 2b, c, d) but the difference was not statistically significant. In summer (exp. I), the total number of Leydig cells per testis was significantly $(P<0.05)$ increased in CB 154injected rams as compared with the controls (fig. $2 \mathrm{e}$ ). There was also a decrease in the profile areas of the Leydig cells (fig. 2f), but the difference was not quite significant $\left(81.7 \pm 2.4\right.$ vs $\left.90.4 \pm 3.0 \mu \mathrm{m}^{2} ; \mathrm{P} \simeq 0.05\right)$. In winter (exp. II), the injection of CB 154 had no effect on the number (fig. 2e) or the size (fig. 2f) of the Leydig cells.

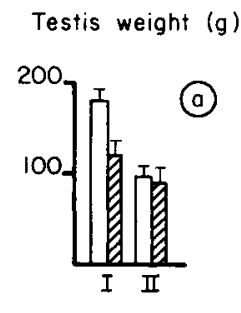

Interstitial tissue volume $\left(\mathrm{cm}^{3}\right)$

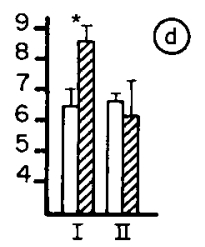

Intertubulor tissue volume $\left(\mathrm{cm}^{3}\right)$

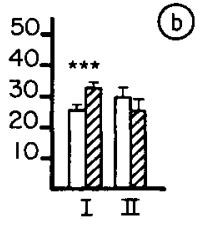

Number of Leydig cells per testis $\left(\times 10^{8}\right)$

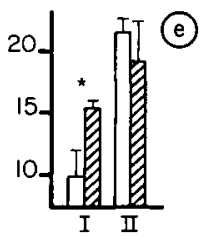

Volume of blood vessels $\left(\mathrm{cm}^{3}\right)$

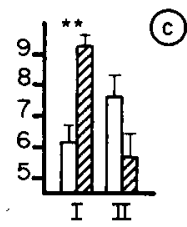

Surface of the Leydig cells $\left(\mu \mathrm{m}^{2}\right)$

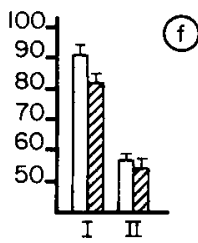

FIG. 2. - Influence of bromocryptine injections on testicular weight and on the morphology of the testicular intertubular compartment (see protocol in Material and methods) (Means \pm SEM). Controls : CB 154-injected rams; Significantly different from controls $\left(^{*}\right) P<0.05$;

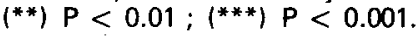

Effects on the tubules and on spermatogenesis (fig. 3). - In the two experiments, the length and diameter of the seminiferous tubules did not differ between the controls and the CB 154-treated rams (fig. 3a, b), nor was there any difference in the number and the area of the nuclear profiles of the Sertoli cells (fig. 3c, d). The rate of spermatogenesis, as indicated by the estimated daily 

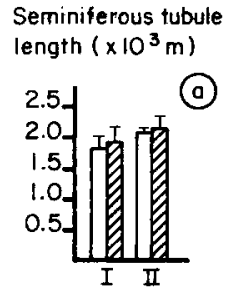

Nuclear surface of the Sertoli cells $\left(\mu \mathrm{m}^{2}\right)$

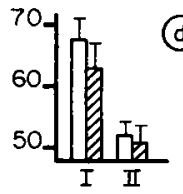

Seminiferous tubule diameter $(\mu \mathrm{m})$

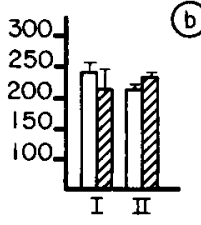

Daily production of Al spermatogonic $\left(\times 10^{7}\right)$

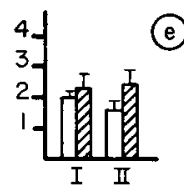

Number of Sertoli cells per testis $\left(\times 10^{8}\right)$

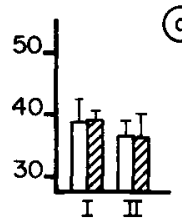

Daily production of round spermatids $\left(\times 10^{8}\right)$

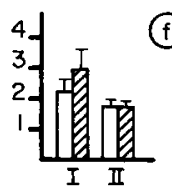

FIG. 3. - Influence of altered prolactin levels on the seminiferous tubules, Sertoli cells and daily production of germ cells in the ram. (Means \pm SEM). $\square$ Controls ; $\square \mathrm{CB} 154$-injected rams.

production of $A_{1}$ spermatogonia and round spermatids, did not differ between control and treated animals in either of the experiments (fig. $3 e, f$ ).

Effects on $\mathrm{LH}$ and FSH binding sites per target cell. - The numbers of $\mathrm{LH}$ binding sites per Leydig cell and FSH binding sites per Sertoli cell, measured at the end of each experiment, were never different between the control and the treated groups (fig. 4). The number of LH receptors per Leydig cell was significantly $(P<0.001)$ correlated with the cross-sectional area of the Leydig cells $(r=0.9 ; n=16)$. The number of $\mathrm{FSH}$ receptors per Sertoli cell was significantly $(P<0.001)$ correlated with the sizes of the Sertoli cell nuclear profiles $(r=0.75 ; n=16)$.
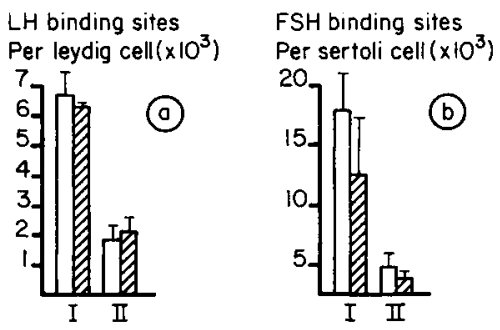

FIG. 4. - Numbers of LH binding sites per Leydig cell and FSH binding sites per Sertoli cell in ram testis after bromocryptine treatment. (Means \pm SEM). $\square$ Controls; $\square$ CB 154-injected rams.

(a): LH binding sites per Leydig cell $\left(\times 10^{3}\right)$.

(b) : FSH binding sites per Sertoli cell $\left(\times 10^{3}\right)$

\section{Discussion.}

The present results show that the delay in the spontaneous recrudescence of the testis, previously observed in rams treated with CB 154 in summer (Barenton and Pelletier, 1980), is associated with modifications in the structure 
of the intertubular tissues (number of Leydig cells, volume of the blood vesseis) and with an increased plasma FSH secretion. Although the use of the statistical test is questionable in this experiment since there are only theree animals per group, it is unlikely that so many changes would occur at random in the same experiment.

A stimulating effect of bromocryptine treatment on FSH levels has also been reported in suckling ewes (Kann et al., 1977) and women (Seki et al., 1974 ; Nader et al., 1975). However, our results contrast with the increased release of FSH in hyperprolactinaemic rats (Voogt et al., 1969), dwarf mice (Bartke et al., 1977) and hamsters (Bartke et al., 1981) and also with the decreased secretion of FSH in men treated with bromocryptine (Lackritz and Bartke, 1980). Thus, there may well be a species-dependent effect of prolactin on FSH release in rams, rodents and humans. This is important in understanding the differential effect of season on the reproductive activity of hamster and ram. We were unable to show any significant change in LH secretion, probably because the blood was sampled too infrequently to reflect quantitatively the episodic secretion of that hormone.

Treatment with CB 154 only in summer induced hyperplasia of the Leydig cells, and their size was a little reduced at the time of measurement. Presumably, hypoprolactinaemia initially allowed the division of these cells, but during subsequent growth they did not reach as large a size as the Leydig cells in the control animals. The monitoring factors in this process are difficult to determine since prolactin (Rajaniemi et al., 1974 ; Charreau et al., 1977), as well as bromocryptine per se (Vermes and Telegdy, 1978) and FSH (Ketelslegers et al., 1978), have been assumed to act directly on the Leydig cells in rodents. Furthermore, an action of LH could not be excluded here. One hypothesis is that the inhibitory effect of hypoprolactinaemia on testicular activity has been compensated by increased FSH, and possibly LH, secretion. This could explain why testicular growth was only delayed.

The number of Sertoli cells per testis in the two experiments did not differ between the treated and the control animals, although it did differ between experiments. Consequently, it was possible to compare the histological data between the treated and the control groups. Such comparisons should not be made between experiments since the number of Sertoli cells is correlated with both the volume of the intertubular tissues and the production of $A_{1}$ spermatogonia (Hochereau-de Reviers and Courot, 1978) and thus, the differences between experiments would not necessarily be caused by the different experimental treatments.

As suggested earlier (Barenton and Pelletier, 1980 ; Barenton, 1981), the evaluation of the number of $\mathrm{LH}$ receptors per Leydig cell confirms that changes in plasma prolactin levels do not affect the regulation of $\mathrm{LH}$ receptors in the ram. In addition, the present results show that the number of FSH receptors per Sertoli cell is likewise unaffected. The correlation between the number of $\mathrm{LH}$ receptors per Leydig cell and the size of the profiles of those cells and the correlation between the number of FSH receptors per Sertoli cell and the size of the nuclear profiles of those cells indicate that $\mathrm{LH}$ and $\mathrm{FSH}$ binding site 
populations are closely related to the size of their respective target cells in the testis.

The summer experiment in particular suggested that the gametogenic function of the ram testis is not impaired by reduced prolactin levels since the injection of bromocryptine did not decrease the daily production of $A_{1}$ spermatogonia and round spermatids. This finding is in agreement with those in bulls (Stolla et al., 1978) and mice (Bartke, 1974). On the other hand, Howles et al. (1980) have shown that a constant long or short light regime induced a precocious, desynchronized and shortened breeding season in rams. These results and ours support the hypothesis that the summer surge of prolactin does not interfere with the sequence but with the timing of the events initiating the breeding season in the ram.

We conclude that, under some conditions, which yet remain to be clearly defined, prolactin can modify the release of at least FSH and the structure of the intertubular tissue. On the other hand, prolactin deficiency causes only a transient delay in testicular growth (Barenton and Pelletier, 1980) and has little or no effect on sperm production. Furthermore, the effects of prolactin were detected only in summer, suggesting that the hypothalamo-pituitary-testicular axis is not continuously sensitive and/or responsive to prolactin in the ram.

Reçu en octobre 1981. Accepté en janvier 1982.

Acknowledgements. - The authors are grateful to Dr. J. Pelletier for advice, to Dr. D. M. Spencer for checking the English and to Mrs. Ghislaine Ploux for typing the manuscript. We thank Sandoz Ltd. for the gift of the $2 \mathrm{br}$ - $\alpha$-ergocryptine. This work was supported by the DGRST grant "Prolactine ".

Résumé. Afin d'étudier les effets de l'hypoprolactinémie provoquée sur les niveaux plasmatiques des hormones gonadotropes et sur la fonction testiculaire, un traitement au CB 154 a été administré chez le bélier, soit en été sous une photopériode naturelle, soit en hiver mais combiné à un traitement lumineux qui stimule la sécrétion de la prolactine.

En été et sous une photopériode naturelle, le niveau plasmatique de la FSH a augmenté de 2,5 à $4 \mathrm{ng} / \mathrm{ml}$ chez les animaux témoins et de $2,5 \mathrm{à} 8 \mathrm{ng} / \mathrm{ml}$ chez les animaux traités au CB 154. La différence entre les deux lots était significative $(P<0,05)$ dès la deuxième semaine de traitement. Chez les animaux photostimulés en hiver, le traitement au CB 154 n'a pas eu d'effet sur la sécrétion de la FSH. Dans les deux expériences, le traitement au CB 154 n'a pas montré d'effet significatif sur les niveaux plasmatiques moyens de la LH.

Le traitement au CB 154 en été a conduit à une augmentation du volume des vaisseaux sanguins péritubulaires et du tissu interstitiel. Le nombre des cellules de Leydig par testicule a significativement $(P<0,05)$ augmenté chez les béliers traités au CB 154. Toutefois, au moment de la mesure, nous n'avons constaté aucune modification de la structure des tubes séminifères ainsi que de la production des cellules germinales. En hiver, le traitement au CB 154 n'a produit aucun effet notable ni sur la structure des tissus interstitiels et tubulaires, ni sur la spermatogenèse.

Le nombre des récepteurs à la $L H$, exprimé par cellule de Leydig, ainsi que le nombre des récepteurs à la FSH, exprimé par cellule de Sertoli, n'ont pas été modifiés par les variations du niveau de la prolactine lors des deux expériences. 
Nous en concluons que l'hypoprolactinémie induite est capable de modifier la sécrétion hypophysaire de la FSH chez le bélier et de changer la structure du tissu intertubulaire. En revanche, elle n'affecte pas le nombre des récepteurs à la $\mathrm{LH}$ et à la $\mathrm{FSH}$ et ne perturbe pas la spermatogenèse.

\section{References}

ABERCROMBIE M., 1946. Estimation of nuclear population from microtome sections. Anat. Rec., 94, 238-248.

ATTAL J., COUROT M., 1963. Développement testiculaire et établissement de la spermatogenèse chez le taureau. Ann. Biol. anim. Biochim. Biophys., 3, 219-241.

BARENTON B., 1981. Failure of short-term hyperprolactinaemia to increase gonadotrophin receptors in the ram testis. J. Endocr., 83, 451-454.

BARENTON B., PELLETIER J., 1980. Prolactin, testicular growth and LH receptors in the ram following light and 2 br- $\alpha$-ergocryptine (CB 154) treatments. Biol. Reprod., 22, 781-790.

BARTKE A., 1974. Effects of inhibitors of pituitary prolactin release on testicular cholesterol stores, seminal vesicle weight, fertility and lactation in mice. Biol. Reprod., 11, 319-325.

BARTKE A., SMITH M. S., MICHAEL S. D., PERON F. G., DALTERIO S., 1977. Effects of experimentally induced chronic hyperprolactinaemia on testosterone and gonadotropin levels in male rats and mice. Endocrinology, 100, 182-186.

BARTKE A., SILER-KHODR T. M., HOGAN M. P., ROYCHOUDHURY P., 1981. Ectopic pituitary transplants stimulate synthesis and release of follicle-stimulating hormone in golden hamsters. Endocrinology, 108, 133-140.

BEX F. J., BARTKE A., GOLDMAN B. D., DALTERIO S., 1978. Prolactin, growth hormone, luteinizing hormone receptors and seasonal changes in testicular activity in the golden hamster. Endocrinology, 103, 2069-2080.

BLANC M. R., POIRIER J. C., 1979. A new homologous radioimmunoassay for ovine folliclestimulating hormone : development and characterization. Ann. Biol. anim. Biochim. Biophys., 19, 1011-1026.

CHARREAU E. H., ATTRAMADAL A., TORJESEN P. A., PURVIS K., CALANDRA R., HANSSON V., 1977. Prolactin binding in rat testis : specific receptors in interstitial cells. Mol. cell. Endocrinol., 6, 303-307.

CHENG K. W., 1975. Properties of follicle-stimulating hormone receptor in cell membranes of bovine testis. Biochem. J., 149, 123-132.

HENNIG A., 1957. Das Problem des Kernmessung. Eine Zusammenfessung und Erweiterung der mikroskopischen Messtechnik, Mikroskopie, 12, 174-203.

HOCHEREAU-de REVIERS M. T., COUROT M., 1978. Sertoli cells and development of seminiferous epithelium. Ann. Biol. anim. Biochim. Biophys., 18, 573-583.

HOWLES C. M., WEBSTER G. M., HAYNES N. B., 1980. The effect of rearing under a long or short photoperiod on testis growth, plasma testosterone and prolactin concentrations and the development of sexual behaviour in rams. $J$. Reprod. Fert., 60, 437-447.

KANN G., 1971. Dosage radioimmunologique de la prolactine plasmatique chez les ovins. $C . R$. Acad. Sci. Paris, Sér. D, 272, 2808-2811.

KANN G., MARTINET J., SHIRAR A., 1977. Modifications of gonadotrophin secretion during natural and artificial hyperprolactinaemia in the ewe, 47-59. In P. G. CROSIGNANI, C. ROBYN, Prolactin and human reproduction. Acad. Press, London.

KETELSLEGERS J. M., HETZEL W. D., SHERINS R. J., CATT K. J., 1978. Developmental changes in testicular gonadotropin receptors : plasma gonadotropins and plasma testosterone in the rat. Endocrinology, 103, 212-222.

KLEMCKE H. G., BARTKE A., 1981. Effect of chronic hyperprolactinaemia in mice on plasma gonadotropin binding sites. Endocrinology, 108, 1763-1768.

LACKRITZ R. M., BARTKE A., 1980. The effect of prolactin on androgen response to human chorionic gonadotropin in normal men. Fert. Steril., 34, 140-143. 
MANCINI R. E., CASTRO A., SEIGUER A. C., 1967. Histological localization of follicle-stimulating and luteinizing hormone in the rat testis. J. Histochem. Cytochem., 15, 516-525.

NADER S., KJELD J. M., BLAIR C. M., TOOLEY M., GORDON H., FRASER T. R., 1975. A study of the effect of CB 154 on serum oestradiol, prolactin and FSH levels in puerperal women. Brit. J. Obst. Gynecol., 82, 750-754.

ORTAVANT R., 1959. Le cycle spermatogénétique chez le bélier. Ann. Zootech., 8, 184-244 and 271-322.

PELLETIER J., KANN G., DOLAIS J., ROSSELIN G., 1968. Dosage radioimmunologique de l'hormone lutéinisante plasmatique chez le mouton. Mise au point de la technique de dosage. C. R. Acad. Sci. Paris, Sér. D, 266, 2291-2294.

PURVIS K., CLAUSEN O. P. F., OLSEN A., HAUG E., HANSSON V., 1979. Prolactin and Leydig cell responsiveness to hCG in the rat. Arch. Androl., 3, 219-230.

RAJANIEMI H., OKSANEN A., VANHA-PERTTULA T., 1974 . Distribution of ${ }^{125} \mathrm{I}$-prolactin in mice and rats. Studies with whole body and microautoradiography. Horm. Res., 5, 6-20.

RAVAULT J. P., ORTAVANT R., 1977. Light control of prolactin secretion in sheep. Evidence for a photoinducible phase during a diurnal rhythm. Ann. Biol. anim. Biochim. Biophys., 17, 459-473.

ROOSEN-RUNGE E. C., GIESEL L. O., 1950. Quantitative studies on spermatogenesis in the albino rat. Am. J. Anat., 87, 1-30.

SEKI K., SEKI M., OMURA T., 1974. Serum FSH rise induced by CB 154 in post-partum women. J. clin. Endocrinol. Metab., 39, 206-208.

STOLLA R., SHAMS D., GIMENEZ T., LEIDL W., 1979. Investigations on the influence of prolactin suppression on reproductive function in bulls. Andrologia, 11, 1-10.

TOWER B. B., CLARK B. R., RUBIN R. T., 1977. Preparation of ${ }^{125}$-polypeptide hormones for radioimmunoassay using glucose oxidase with lactoperoxidase. Life Sci., 21, 959-966.

VERMES I., TELEGDY G., 1978. In vitro method of studying the site of action of bromocryptine on hypothalamo-pituitary-testis function in rats. Int. J. Androl., 1, 523-530.

VOOGT J. L., CLEMENS J. A., MEITES J., 1969. Stimulation of pituitary FSH release in immature female rats by prolactin implants in median eminence. Neuroendocrinology, 4, 157-163.

ZIPF W. B., PAYNE A. H., KELCH R. P., 1978. Prolactin, growth hormone and luteinizing hormone in the maintenance of testicular luteinizing hormone receptors. Endocrinology, 103, 595-600. 